\title{
Association of Systemic Immune-inflammation Index With Short-Term Mortality of Congestive Heart Failure: A Retrospective Cohort Study
}

$1 \quad$ Yiyang Tang${ }^{1}$, Xiaofang Zeng ${ }^{1}$, Yilu Feng ${ }^{1}$, Qin Chen ${ }^{1}$, Zhenghui Liu ${ }^{2}$, Hui Luo ${ }^{3}$, Lihuang

$2 \mathbf{Z h a}^{\mathbf{1}^{*}}$ and Zaixin $\mathbf{Y u}^{1,4^{*}}$

$3{ }^{1}$ Department of Cardiology, Xiangya Hospital, Central South University, Changsha, Hunan, People's

4 Republic of China

$5{ }^{2}$ Department of Neurology, Xiangya Hospital, Central South University, Changsha, Hunan, People’s

6 Republic of China

$7{ }^{3}$ Department of Cardiovascular Medicine, the First Hospital of Changsha, Changsha, Hunan,

8 People's Republic of China

$9{ }^{4}$ National Clinical Research Center for Geriatric Disorders (Xiang Ya), Changsha, Hunan, People's

10 Republic of China

$11 *$ Correspondence:

12 Zaixin $\mathrm{Yu}$

13 yuzaixin@126.com

14 Lihuang Zha

15 zhalihuang@csu.edu.cn

16 Keywords: congestive heart failure, systemic immune-inflammation index2, mortality 17 biomarker4, MIMIC-III5.

\section{Abstract}

Purpose: The present study aimed to clarify the potential predictive significance of Systemic immune-inflammation index (SII) in assessing the poor prognosis of critically ill patients with congestive heart failure (CHF).

Methods: Detailed clinical data were extracted from the Multiparameter Intelligent Monitoring in Intensive Care III database after gaining access and building the local platform. The 30- and 90-day and hospital all-cause mortalities of the patient was the primary outcome, and the readmission rate and the occurrence of major cardiovascular adverse events (MACEs) were the secondary outcomes. the Cox proportional hazard model and Logistic regression analysis were selected to reveal the relationship between SII level and the research outcome. Further, the propensity score matching (PSM) analysis was performed to improve the reliability of results by reducing the imbalance across groups.

Results: There were a total of 4606 subjects who passed the screening process and entered the subsequent analysis. Multivariate regression analysis showed that after adjusting for possible confounders, including age, heart rate, and albumin, etc., the high level of SII was independently associated with 30- and 90-day and hospital mortalities (tertile 3 versus tertile 1: HR, 95\% CIs: 1.23, 1.04-1.45; 1.21, 1.06-1.39; 1.26, 1.05-1.50) and the incidence of MACEs (tertile 3 versus tertile 1: OR, 95\% CI: 1.39, 1.12-1.73) in critically ill patients with CHF, but no significant correlation was 
medRxiv preprint doi: https://doi.org/10.1101/2021.08.03.21261549; this version posted August 6, 2021. The copyright holder for this preprint

(which was not certified by peer review) is the author/funder, who has granted medRxiv a license to display the preprint in perpetuity.

All rights reserved. No reuse allowed without permission.

SII in heart failure

36

37

38

39

40

41

42

43

44

45

46

47

48

49

50

51

52

53

54

55

56

57

58

59

60

61

62

63

64

65

66

67

68

69

70

71

72

73

74

75

76

77

78

found between SII and the readmission rate. Consistently, patients with high SII level still presented a significantly higher short-term mortality than patients with low SII in the PSM subset.

Conclusion: In critically ill patients with CHF, high level of SII could effectively predict high 30and 90-day and hospital mortalities, as well as the high risk of occurrence of MACEs.

\section{Introduction}

Congestive heart failure (CHF) is defined as a pathological condition in which the cardiac output is insufficient to maintain the perfusion and metabolic needs of various tissues and organs, mainly characterized by the congestion of pulmonary circulation, accompanied by the corresponding clinical manifestations such as shortness of breath and decreased activity tolerance(Sun et al., 2020). CHF is the severe or terminal stage of most primary cardiovascular diseases and has increasingly become a major public problem threatening human health. In the United States and Europe, more than 1 million heart failure patients are hospitalized each year, and as the population ages, this number is expected to increase by more than $50 \%$ in the next 15 years(Povsic, 2018). In addition, although some progress has been made in the treatment in recent years, the prognosis of CHF patients is still poor, with 5-year mortality rate as high as $40-50 \%$ (Chen et al., 2011). Therefore, accurate assessment and stratification of prognosis are critical to the clinical management of CHF, and the development of certain prognostic-related biomarkers is also pressing, which can help clinicians to identify high-risk patients early and take more aggressive treatment measures(Xu et al., 2021).

Although the specific pathogenesis of heart failure remains unclear, abnormal immune activation and chronic inflammation play an important role. The damage, repair and remodeling of myocardium are the important link in the occurrence and development of heart failure, of which immune/inflammatory cells (neutrophils, lymphocytes, etc.) and the inflammatory factors (tumor necrosis factor, interleukin-6, etc.) released by them are involved(Li et al., 2021). Inflammatory factors can induce cardiomyocyte hypertrophy, apoptosis and fibrosis, and ultimately lead to adverse cardiac remodeling and progressive left ventricular dysfunction(Bradham et al., 2002). Inflammatory factors have been considered to be biomarkers for poor prognosis of heart failure, and antiinflammatory therapy is also expected to become a new target for the treatment of heart failure(Mann, 2015).

Systemic immune-inflammation index (SII) is a composite inflammatory indicator that combines three significant immune cells, including neutrophil, lymphocyte, and platelet, and is considered to be an excellent indicator of local immune response and systemic inflammation(Wang et al., 2016). Neutrophils, platelets and the cytokines they produce are mainly related to non-specific immune responses, while lymphocytes are considered to be mainly related to specific immune pathways. Compared with the absolute count of single immune cells, SII has a better representation in reflecting the inflammation status of the body, with better stability. Until now, SII has been confirmed to be closely correlated with the poor prognosis of a variety of cardiovascular diseases, including coronary artery disease(Yang et al., 2020), aortic stenosis(Tosu et al., 2021), infective endocarditis(Agus et al., 2020), etc., showing good application prospects, but no studies have shown that SII is correlated with the prognosis of patients with CHF. In view of this, the present study attempted to elucidate the independent association between SII and the occurrence of adverse events such as short-term mortality in critically ill patients with CHF, so as to provide reference for the prevention and treatment of heart failure.

\section{Materials and Methods}




\subsection{Data Sources}

80

81

82

83

84

85

86

87

88

89

90

91

92

93

94

95

96

97

98

99

100

101

102

103

104

105

106

107

108

109

110

111

112

113

114

115

116

All data used in the research and analysis of this study are derived from MIMIC-III (Medical Information Mart for Intensive Care III) database, a free and open-access large-scale critical care medicine database developed and run by the Massachusetts Institute of Technology for researchers all over the world. Another advantage of this database, in addition to including the detailed clinical data such as demographic data, vital signs, laboratory tests, and various treatment information, is that it provides accurate death information of all subjects, including time of death in the hospital or within 90 days after discharge, which makes it possible for the clinicians to carry out the prognostic related research. Besides, since this database has been approved by the local ethics committee as a whole and the individual identifying information of the research subjects has been deleted, this study no longer needs additional ethical approval.

\subsection{Population Selection and Exclusion}

The subjects of this study are all from the MIMIC-III database(Johnson et al., 2016), and patients who meet all the following requirements are included in the subsequent analysis: (1) Patients diagnosed with CHF based on the ICD-9 code (code 428.0); (2) Adult patients 18 years of age and older; (3) First admission to ICU. Patients who met one of the following criteria were excluded from the study: (1) The length of ICU stay was shorter than 24 hours; (2) Absence of SII results during hospitalization; (3) Survival time was less than 0 (the time of death of some organ donors may be earlier than the admission).

\subsection{Study Outcomes}

The short-term mortality, including the 30- and 90-day and hospital all-cause mortalities of critically ill patients with CHF, were selected as the primary study outcome, while the secondary study outcome events were defined as the patients' readmission rate and the occurrence of major adverse cardiac events (MACEs), which is a composite outcome event, including all-cause death, readmission for acute heart failure, the use of mechanical circulatory support and the implementation of heart transplantation(Li et al., 2020).

\subsection{Data Extraction and Integration}

Through the PostgreSQL software (version 9.6, https://www.postgresql.org/), we extracted detailed clinical data of the research subjects from the MIMIC-III database, including demographic data (age, gender, race, etc.), comorbidities (hypertension, diabetes mellitus, atrial fibrillation, etc.), vital signs (heart rate, blood pressure, respiratory rate, etc.), severity of illness scores (SOFA and SAPSII scores), laboratory tests (blood routine, electrolytes, etc.) and intervention measures (dialysis, mechanical ventilation, etc.). And the value of SII is equal to the product of the platelet count and the neutrophil count divided by the lymphocyte count(Hu et al., 2014).

After separately extracting the required tables from the MIMIC-III database, the Stata software (version 16, https://www.stata.com/) was used to process and merge these original table and generate a complete table that can be used for subsequent analysis. Use the "winsorize" function to identify and process outliers, and fill in missing values through multiple compensation methods.

\subsection{Statistical Analyses}

The continuous variables were presented in the form of mean \pm standard deviation (SD) or median (interquartile range). If continuous variables satisfy both normal distribution and homogeneity of 
medRxiv preprint doi: https://doi.org/10.1101/2021.08.03.21261549; this version posted August 6, 2021. The copyright holder for this preprint (which was not certified by peer review) is the author/funder, who has granted medRxiv a license to display the preprint in perpetuity.

variance, t-test was used for analysis, while the Mann-Whitney $\mathrm{U}$ test was conducted if the normal distribution or homogeneity of variance were not satisfied. Categorical variables are expressed in the form of the number of cases (percentage), with the chi-square test (or Fisher's exact method) for 123 analysis.

124 We constructed a generalized additive model (GAM) to determine the non-linear relationship between SII and 30- and 90-day all-cause mortalities in critically ill patients with CHF. In addition, we also visually show the relationship between SII and patients' survival through the Kaplan-Meier (K-M) curve, and use the Log-rank test for hypothesis testing.

In order to relieve the interference of possible confounding factors on the results, we completed univariate and multivariate regression analysis to further clarify the relationship between SII and outcome variables. In the crude model, no variables were adjusted. In model I, the age, gender, and race variables were adjusted, while model II further adjusted other 13 variables on the basis of these variables of model II, including heart rate, blood urea nitrogen (BUN), albumin, troponin T (cTnT), $\mathrm{N}$-terminal probrain natriuretic peptide (NT-proBNP), urine output of first day, cardiac index, the type of first ICU admission, the use of mechanical ventilation and vasopressor, pneumonia, and liver diseases. The selection of confounding factors follows the following principles(Jaddoe et al., 2014): (1) A certain factor has an influence of more than $10 \%$ on the research variable; (2) Some factors may have a significant impact on the outcome variable based on past experience. Besides, we used the variance inflation factor (VIF) to test the multicollinearity between variables with 5 as the threshold, and the variables with a high degree of collinearity, serum chloride, were deleted to avoid over-fitting of the model. The Cox regression analysis was used to determine the relationship between SII and short-term mortalities in critically ill patients with CHF, while Logistic regression analysis was used to analyze the association between SII and readmission rates or MACEs.

143 To further enhance the credibility of our analysis, we performed the subgroup analysis and 144 propensity score matching (PSM) analysis. First, By the subgroup analysis, determine whether the correlation between the SII and the high 30-day all-cause mortality in critically ill patients with CHF was consistent across various subgroups stratified mainly by comorbidities, and reflect the stability of SII as a prognostic marker. The optimal cut-off value of SII for the short-term mortality was determined by the X-tile (version 3.6.1, Yale University School of Medicine) software, and then the entire study population was divided into two groups, namely the high SII group and the low SII group. In this study, all variables with uneven distribution between the two groups of patients were included in the PSM model as covariates, and the corresponding propensity score was calculated by Logistic regression. Then the two groups of individuals with similar propensity scores were matched by $1: 1$ using nearest neighbor matching method with a caliper width of 0.05 , and the histogram of the propensity score distribution was draw, which was carried out through the Stata software. Then, K-M curves were depicted and Cox regression analysis was conducted in the matching cohort after PSM, which further validated SII as an independent risk factor for poor prognosis in the critically ill patients with CHF.

158 The statistical analysis above was conducted by EmpowerStats software (version 2.20, 159 http://www.empowerstats.com/cn/, X\&Y solutions, Inc, Boston, MA) and R software (version 3.4.3). $160 \mathrm{p}<0.05$ (two-sided) was considered statistically significant.

\section{$\begin{array}{lll}161 & 3 & \text { Results }\end{array}$}

\section{$162 \quad 3.1 \quad$ Clinical Characteristics of Study Subjects}


The study subjects were screened according to the process mentioned above, and 4606 subjects were finally included. The demographic data, vital signs, comorbidities, treatment, scores and laboratory examinations and other relevant information are shown in Table 1 in detail. In general, the study subjects included were a little old, with a median age of 74.91 years old, mainly male patients, reaching 2436 , accounting for $52.89 \%$. And the majority of the subjects were whites, accounting for $72.71 \%$, blacks only $7.21 \%$, and other races including Asians accounted for $20.08 \%$. The duration of follow-up was 90 days, of which 3226 survived and 1380 died due to various reasons before the end of the study. SII (213.97 vs $163.11, \mathrm{p}<0.001)$ was significantly higher in the non-survivor cohort. Compared with the survivor group, older patients were identified more frequently in the non-survivor group, with more unstable vital signs, higher incidence of comorbidities such as VHD, atrial fibrillation, and renal failure, as well as higher SOFA and SAPSII scores.

\subsection{SII Distinguishing a Poor Short-term Prognosis}

GAM analysis was used to identify the non-linear correlation between SII and the short-term allcause mortality of patients, which showed that there was a U-shaped curve relationship between SII and 30-day (Figure 1A) and 90-day (Figure 1B) all-cause mortalities in critically ill patients with $\mathrm{CHF}$, indicating that higher or lower SII may be associated with increased mortality. The K-M survival curve (Figure 2) also showed that compared with the low SII group, patients with high SII level had a lower overall survival rate and shorter survival time, with a statistically significant $p$ value.

In order to verify the independent relationship between SII and the poor short-term mortality of CHF stratified by tertiles. In crude model, the third tertile of SII increased significantly the risk of 30- (HR, 95\% CI: 1.73, 1.48-2.03) and 90-day (HR, 95\% CI: 1.65, 1.45-1.88) and hospital (HR, 95\% CI: 1.61, 1.36-1.91) all-cause mortalities compared with the first tertile. In multivariate model I, after adjusting for age, sex, and race, the third tertile of SII group also suffered from the higher risk of 30- (HR, 95\% CI: 1.63, 1.40-1.91) and 90-day (HR, 95\% CI: 1.57, 1.38-1.79) and hospital (HR, 95\% CI: 1.45, $1.22-$ 1.72) all-cause mortalities. In model II, in addition to adjusting for the variables in model I and other possible confounders such as pneumonia, the use of dialysis, and BUN level, high levels of SII were still strongly associated with poor 30- (HR, 95\% CI: 1.23, 1.04-1.45) and 90-day (HR, 95\% CI: 1.21 , 1.06-1.39) and hospital (HR, 95\% CI: 1.26, 1.05-1.50) all-cause mortalities.

\subsection{Association between SII and Readmission and MACEs} still at higher incidence of MACEs (OR, 95\% CI: 1.39, 1.12-1.73). However, in the multivariate regression analysis, there was no obvious independent correlation between SII and readmission rate in the critically ill patients with CHF (tertile 3 versus tertile 1: OR, 95\% CI: 0.97, 0.81-1.15).

\subsection{Subgroup Analyses}

The subgroup analysis was conducted to reveal the correlation between SII and 30-day mortality across comorbidities and different parameters, and the results were shown in Table 4. First, the results of the study showed that in all subgroups, the increase in SII level was closely related to the increase in the 30-day all-cause mortality of critically ill patients with CHF. Besides, most of the stratification factors have not been found to have a significant impact on the relationship between the SII and 30-day all-cause mortality (interaction $p$ value $>0.05)$, except for hyperlipemia $(p=0.006)$ and acute myocardial infarction (AMI, $p=0.016$ ). 
medRxiv preprint doi: https://doi.org/10.1101/2021.08.03.21261549; this version posted August 6, 2021. The copyright holder for this preprint

\subsection{Prognostic Value of SII After PSM}

207 Determine the optimal cut-off value of SII for 90-day all-cause mortality of critically ill patients with

208 CHF through X-tile software, which is 5533.4. Subjects were divided into two groups according to

209

210 the cut-off value, and their clinical characteristics were summarized in Table 5, most of which were unevenly distributed across the two groups. In order to effectively balance these confounding factors and improve the credibility of our results, we conducted a PSM analysis with 1:1 matching. After PSM, 602 pairs of research objects were generated and the difference of almost all variables were balanced between the two groups, with a good matching performance (Figure 3). At the same time, after PSM, compared with the low SII level group, subjects in the high SII level group still underwent higher 30- (24.9\% vs 33.2\%, $p=0.002)$ and 90 -day $(35.0 \%$ vs $42.0 \%, p=0.013)$ and hospital $(22.4 \%$ vs $27.7 \%, p=0.033)$ all-cause mortalities, with shorter survival time (Table 5 and Figure 4). Besides, after adjusting for these covariable in the model II, the increased SII was also associated with increased risk of short-term all-cause mortality in critically ill patients with CHF after PSM and the results were shown in Figure 5 in the form of a forest map.

\section{Discussion}

CHF is widespread all over the world, with gradually increasing incidence with age, and has become one of the diseases with the highest rates of hospitalizations and deaths in the world, bringing about enormous medical expenditure and social burden, especially in developing countries(Savarese and Lund, 2017). In addition to exploring promising treatments, the development of novel prognostic markers for risk stratification of patients is also of great value for improving the prognosis of patients. As we all know, as a commonly used indicator of heart failure, NT-proBNP can make a good performance in prognostic evaluation. However, the clinical applications of NT-proBNP for risk assessment has some drawbacks and problems. First, compared to the real value, the detection of NT-proBNP tend to be underestimated because of the short half-life. Moreover, the test of NTproBNP may be affected by various factors such as age, gender, and kits(Cho et al., 2020). Therefore, the search for more possible biomarkers has gradually attracted the attention of researchers and clinicians.

In the present study, we extracted the clinical data of 4606 critically ill patients who diagnosed with CHF between 2001 and 2012 in MIMIC-III database, and analyzed the relationship between SII and short-term prognosis by univariate and multivariate regression analyses for the first time. And the results have verified that SII could be an independent biomarker for poor short-term prognosis of CHF. There was a nonlinear relationship between SII and 30- and 90-day mortalities. And the higher SII level, the higher risk of 30- and 90-day and hospital mortalities, as well as the higher incidence of MACEs. The correlation remained significant after adjusting for possible confounders, stratifying according to comorbidities, and PSM matching, respectively.

Inflammation, a widely accepted hallmark of heart failure, has been proven to play an indispensable role in the pathogenesis of heart failure(Dick and Epelman, 2016). The increase and activation of inflammation-related cytokines not only present a reflection of the activation of inflammation in vivo, but have also been identified as being associated with poor prognosis in heart failure. Tumor necrosis factor $\alpha$ (TNF- $\alpha$ ) was the first cytokine found to be significantly elevated in the serum of patients with heart failure, which could directly induce myocardial apoptosis and necrosis, bringing about ventricular adverse remodeling(Anker and von Haehling, 2004). The elevated levels of TNF- $\alpha$ often indicated impaired cardiac systolic function and poor long-term survival(Rauchhaus et al., 2000). In addition, interleukin 6 (IL-6), another classic cytokine mainly derived from monocytes, 
medRxiv preprint doi: https://doi.org/10.1101/2021.08.03.21261549; this version posted August 6, 2021. The copyright holder for this preprint (which was not certified by peer review) is the author/funder, who has granted medRxiv a license to display the preprint in perpetuity.

250

251

252

253

254

255

256

257

258

259

260

261

262

263

264

265

266

267

268

269

270

271

272

273

274

275

276

277

278

279

280

281

282

283

284

285

286

287

288

289

290

291

292

293

294

295

296

297 could be significantly increased in patients with left ventricular systolic dysfunction without clinical symptoms, and may be a sensitive indicator for the early diagnosis of heart failure(Plenz et al., 2001). IL-6 was also positively correlated with the severity of heart failure, the concentration of which was negatively correlated with left ventricular ejection fraction and overall survival(MarkousisMavrogenis et al., 2019). Although these inflammatory molecules had good performance in the prognostic evaluation of patients, the expensive detection cost limited their clinical application. As a novel biomarker, SII can systematically and comprehensively reflect the status of inflammation in vivo. Blood routine is a routine examination for almost all hospitalized patients. It is simple, fast, and inexpensive. Compared with NT-proBNP, cytokines and other prognostic indicators, SII can effectively screen high-risk patients, guide the formulation of individualized treatment plans and improve the prognosis of patients without additional cost, with a broad application prospect, especially in underdeveloped areas.

The mechanisms of the relationship between SII and adverse prognosis of CHF remains unclear, and possible explanations are as follows. Recently, it has been revealed that circulating immune cells and their subtypes had a vital indicative effect on the prognosis of cardiovascular diseases(Strassheim et al., 2019). SII was a prognostic indicator that integrates three circulating immune cells, including neutrophils, lymphocytes, and platelets, the increase of which indicates either a relative increase in platelets and neutrophils counts or a relative decrease in lymphocytes. Neutrophils are the main component of white blood cells, accounting for $60-70 \%$ of the total, and play an important role in the non-specific immune system. In the inflammatory response, neutrophils react rapidly, with strong chemotaxis and phagocytosis, and participate in the progression of various cardiovascular diseases, including heart failure(Bonaventura et al., 2019). In addition, neutrophils could contribute to oxidative stress and endothelial dysfunction by releasing a large amount of myeloperoxidase, NADPH oxidase, and so on(Swirski and Nahrendorf, 2013). According to a community-based study(Arruda-Olson et al., 2009), absolute neutrophils can effectively predict the increased incidence of acute decompensated heart failure after AMI, and it was also an independent risk factor for death(Uthamalingam et al., 2011). Lymphocytes mainly consist of two subtype including T and B cells, which were often associated with the specific immunity. Several previous studies have reported that lymphocyte counts in patients with heart failure were lower than in the normal population and lymphopenia served as an independent predictor of poor survival of patients with chronic and advanced heart failure(Charach et al., 2011; Vaduganathan et al., 2012). Lymphopenia was considered to be an important feature of systemic inflammation, which may be caused by the following mechanisms. First, the circulating lymphocytes were attracted into the cardiac tissue, leading to its redistribution. Then, lymphopenia was related to the activation of renin-angiotensinaldosterone hormone and the adrenergic nervous system, which could exert pro-apoptotic effects on lymphocytes(Charach et al., 2011). Platelets were differentiated from the mononuclear-phagocyte system and were the key mediator linking the two pathological processes of inflammation and thrombosis(Ye et al., 2019). On the one hand, platelets were the main effector molecules for hemostasis after cardiovascular injury. On the other hand, the activation of platelets plays a major role in pathogenic thrombosis and participates in the pathogenesis of many groups of cardiovascular diseases, including coronary heart disease(Glezeva et al., 2016). Moreover, Platelets interacted with leukocytes and their subtypes (neutrophil, lymphocytes, etc.) and endothelial cells and activated them, inducing monocyte adhesion and transport, releasing inflammatory factors such as TNF- $\alpha$ and IL-1, which together promoted local inflammation and fibrosis in heart failure(Glezeva et al., 2016). The study by Kandis(Kandis et al., 2011) et al. demonstrated that mean platelet volume (MPV), indicating the activation of platelets, increased significantly in decompensated heart failure patients. In addition, MPV at admission was independently associated with the hospital and 6-month mortalities. 
Besides, the subgroup analysis was also conducted, and the results demonstrated that the association was stable and consistent between the high level of SII and the poor 30-day mortality across CHF patients with different comorbidities or severity scores. We also noted that, among the critically ill patients with CHF, patients complicated with AMI and hyperlipidemia had a higher risk of 30-day mortality, and this risk was higher for higher SII, which implied that SII may be more valuable for the prognostic evaluation of CHF patients with AMI or hyperlipidemia. Similarly, the previous study has also shown that in patients with coronary heart disease, the high level of SII indicated a high risk of cardiac death in the future, as well as the high incidence of non-fatal stroke and heart failure(Yang et al., 2020). Although there was no research on the correlation between SII and hyperlipidemia, the interconnection of hyperlipidemia and inflammation involved in the pathogenesis of cardiovascular disease has been recognized(Rodriguez-Garcia and Alcaide, 2021).

As a retrospective cohort study, the existence of confounding factors cannot be ignored, and it was difficult to intuitively and accurately judge the correlation between SII level and the prognosis of CHF patients. Another highlight of this study was the use of PSM analysis to reduce the imbalance of confounding factors across different groups. After PSM, the most baseline characteristics were wellbalanced between these two groups, except for the use of dialysis, the type of first ICU admission, and the peripheral vascular diseases. More importantly, the conclusion that high levels of SII were independently related to high short-term mortality remained stand before and after PSM, which improved the reliability of SII as a prognostic marker of CHF.

\section{Conclusion}

326 In summary, the high level of SII is closely related to the poor short-term prognosis in critically ill

327 patients with CHF, including 30- and 90-day and hospital all-cause mortalities, as well as the

328 occurrence of MACEs, and is expected to be a simple and effective prognostic evaluation indicator.

\section{$329 \quad 6 \quad$ Conflict of Interest}

330 All authors declare that there is no conflict of interest.

\section{Author Contributions}

332 Zaixin $\mathrm{Yu}$ and Lihuang Zha are the senior author who conceived and designed the study. Yiyang

333 Tang and Xiaofang Zeng collected and analyzed the clinical data. Yiyang Tang drafted the

334

335

336

337 manuscript. Yilu Feng and Qin Chen participated in the implementation of statistical methods in this study and put forward constructive suggestions. Zhenghui Liu and Hui Luo reviewed the study and participated in the interpretation of the results. All authors gave final approval of the version to be published, and agree to be accountable for all aspects of the work.

\section{$338 \quad 8 \quad$ Funding}


medRxiv preprint doi: https://doi.org/10.1101/2021.08.03.21261549; this version posted August 6, 2021. The copyright holder for this preprint (which was not certified by peer review) is the author/funder, who has granted medRxiv a license to display the preprint in perpetuity.

339

340

341

342

343

344

345

346

347

348

349

350

351

352

353

354

355

356

357

358

359

360

361

362

363

364

365

366

367

368

369

370

371

372

373

374

375

376

377

Our study was supported by the National Natural Science Foundation of China (81873416), the Key Research and Development Program of Hunan Province (2020SK2065) and Natural Science Foundation Project of Hunan Province (2020JJ4634).

\section{Data availability}

Publicly available datasets were analyzed in this study. This data can be extracted from Monitoring in Intensive Care Database III version 1.4 (MIMIC-III v.1.4) after passing on the required courses and obtaining the authorization.

\section{Reference styles}

Agus, H.Z., Kahraman, S., Arslan, C., Yildirim, C., Erturk, M., Kalkan, A.K., et al. (2020). Systemic immune-inflammation index predicts mortality in infective endocarditis. J Saudi Heart Assoc 32(1), 58-64. doi: 10.37616/2212-5043.1010.

Anker, S.D., and von Haehling, S. (2004). Inflammatory mediators in chronic heart failure: an overview. Heart 90(4), 464-470. doi: 10.1136/hrt.2002.007005.

Arruda-Olson, A.M., Reeder, G.S., Bell, M.R., Weston, S.A., and Roger, V.L. (2009). Neutrophilia predicts death and heart failure after myocardial infarction: a community-based study. Circ Cardiovasc Qual Outcomes 2(6), 656-662. doi: 10.1161/CIRCOUTCOMES.108.831024.

Bonaventura, A., Montecucco, F., Dallegri, F., Carbone, F., Luscher, T.F., Camici, G.G., et al. (2019). Novel findings in neutrophil biology and their impact on cardiovascular disease. Cardiovasc Res 115(8), 1266-1285. doi: 10.1093/cvr/cvz084.

Bradham, W.S., Bozkurt, B., Gunasinghe, H., Mann, D., and Spinale, F.G. (2002). Tumor necrosis factor-alpha and myocardial remodeling in progression of heart failure: a current perspective. Cardiovasc Res 53(4), 822-830. doi: 10.1016/s0008-6363(01)00503-x.

Charach, G., Grosskopf, I., Roth, A., Afek, A., Wexler, D., Sheps, D., et al. (2011). Usefulness of total lymphocyte count as predictor of outcome in patients with chronic heart failure. Am J Cardiol 107(9), 1353-1356. doi: 10.1016/j.amjcard.2010.12.049.

Chen, J., Normand, S.L., Wang, Y., and Krumholz, H.M. (2011). National and regional trends in heart failure hospitalization and mortality rates for Medicare beneficiaries, 1998-2008. JAMA 306(15), 1669-1678. doi: 10.1001/jama.2011.1474.

Cho, J.H., Cho, H.J., Lee, H.Y., Ki, Y.J., Jeon, E.S., Hwang, K.K., et al. (2020). NeutrophilLymphocyte Ratio in Patients with Acute Heart Failure Predicts In-Hospital and Long-Term Mortality. J Clin Med 9(2). doi: 10.3390/jcm9020557.

Dick, S.A., and Epelman, S. (2016). Chronic Heart Failure and Inflammation: What Do We Really Know? Circ Res 119(1), 159-176. doi: 10.1161/CIRCRESAHA.116.308030.

Glezeva, N., Gilmer, J.F., Watson, C.J., and Ledwidge, M. (2016). A Central Role for MonocytePlatelet Interactions in Heart Failure. J Cardiovasc Pharmacol Ther 21(3), 245-261. doi: $10.1177 / 1074248415609436$.

Hu, B., Yang, X.R., Xu, Y., Sun, Y.F., Sun, C., Guo, W., et al. (2014). Systemic immuneinflammation index predicts prognosis of patients after curative resection for hepatocellular carcinoma. Clin Cancer Res 20(23), 6212-6222. doi: 10.1158/1078-0432.CCR-14-0442. 
medRxiv preprint doi: https://doi.org/10.1101/2021.08.03.21261549; this version posted August 6, 2021. The copyright holder for this preprint (which was not certified by peer review) is the author/funder, who has granted medRxiv a license to display the preprint in perpetuity.

378

379

380

381

382

383

384

385

386

387

388

389

390

391

392

393

394

395

396

397

398

399

400

401

402

403

404

405

406

407

408

409

410

411

412

413

414

415

416

417

418

419

Jaddoe, V.W., de Jonge, L.L., Hofman, A., Franco, O.H., Steegers, E.A., and Gaillard, R. (2014). First trimester fetal growth restriction and cardiovascular risk factors in school age children: population based cohort study. BMJ 348, g14. doi: 10.1136/bmj.g14.

Johnson, A.E., Pollard, T.J., Shen, L., Lehman, L.W., Feng, M., Ghassemi, M., et al. (2016). MIMICIII, a freely accessible critical care database. Sci Data 3, 160035. doi: 10.1038/sdata.2016.35.

Kandis, H., Ozhan, H., Ordu, S., Erden, I., Caglar, O., Basar, C., et al. (2011). The prognostic value of mean platelet volume in decompensated heart failure. Emerg Med J 28(7), 575-578. doi: 10.1136/emj.2009.088401.

Li, H., Chen, C., and Wang, D.W. (2021). Inflammatory Cytokines, Immune Cells, and Organ Interactions in Heart Failure. Front Physiol 12, 695047. doi: 10.3389/fphys.2021.695047.

Li, W., Huang, A., Zhu, H., Liu, X., Huang, X., Huang, Y., et al. (2020). Gut microbiota-derived trimethylamine $\mathrm{N}$-oxide is associated with poor prognosis in patients with heart failure. Med $J$ Aust 213(8), 374-379. doi: 10.5694/mja2.50781.

Mann, D.L. (2015). Innate immunity and the failing heart: the cytokine hypothesis revisited. Circ Res 116(7), 1254-1268. doi: 10.1161/CIRCRESAHA.116.302317.

Markousis-Mavrogenis, G., Tromp, J., Ouwerkerk, W., Devalaraja, M., Anker, S.D., Cleland, J.G., et al. (2019). The clinical significance of interleukin-6 in heart failure: results from the BIOSTAT-CHF study. Eur J Heart Fail 21(8), 965-973. doi: 10.1002/ejhf.1482.

Plenz, G., Song, Z.F., Tjan, T.D., Koenig, C., Baba, H.A., Erren, M., et al. (2001). Activation of the cardiac interleukin-6 system in advanced heart failure. Eur J Heart Fail 3(4), 415-421. doi: 10.1016/s1388-9842(01)00137-4.

Povsic, T.J. (2018). Emerging Therapies for Congestive Heart Failure. Clin Pharmacol Ther 103(1), 77-87. doi: 10.1002/cpt.913.

Rauchhaus, M., Doehner, W., Francis, D.P., Davos, C., Kemp, M., Liebenthal, C., et al. (2000). Plasma cytokine parameters and mortality in patients with chronic heart failure. Circulation 102(25), 3060-3067. doi: 10.1161/01.cir.102.25.3060.

Rodriguez-Garcia, M., and Alcaide, P. (2021). Vascular Inflammation and Hyperlipidemia: The Neutrophil Within. JACC Basic Transl Sci 6(6), 524-526. doi: 10.1016/j.jacbts.2021.05.006.

Savarese, G., and Lund, L.H. (2017). Global Public Health Burden of Heart Failure. Card Fail Rev 3(1), 7-11. doi: 10.15420/cfr.2016:25:2.

Strassheim, D., Dempsey, E.C., Gerasimovskaya, E., Stenmark, K., and Karoor, V. (2019). Role of Inflammatory Cell Subtypes in Heart Failure. J Immunol Res 2019, 2164017. doi: $10.1155 / 2019 / 2164017$.

Sun, D., Zhang, F., Ma, T., Zhang, Y., and Liang, Z. (2020). Atorvastatin alleviates left ventricular remodeling in isoproterenol-induced chronic heart failure in rats by regulating the RhoA/Rho kinase signaling pathway. Pharmacol Rep 72(4), 903-911. doi: 10.1007/s43440-020-00085-3.

Swirski, F.K., and Nahrendorf, M. (2013). Leukocyte behavior in atherosclerosis, myocardial infarction, and heart failure. Science 339(6116), 161-166. doi: 10.1126/science.1230719.

Tosu, A.R., Kalyoncuoglu, M., Biter, H.I., Cakal, S., Selcuk, M., Cinar, T., et al. (2021). Prognostic Value of Systemic Immune-Inflammation Index for Major Adverse Cardiac Events and Mortality in Severe Aortic Stenosis Patients after TAVI. Medicina (Kaunas) 57(6). doi: 10.3390/medicina57060588. 
medRxiv preprint doi: https://doi.org/10.1101/2021.08.03.21261549; this version posted August 6, 2021. The copyright holder for this preprint

(which was not certified by peer review) is the author/funder, who has granted medRxiv a license to display the preprint in perpetuity.

Uthamalingam, S., Patvardhan, E.A., Subramanian, S., Ahmed, W., Martin, W., Daley, M., et al. (2011). Utility of the neutrophil to lymphocyte ratio in predicting long-term outcomes in acute decompensated heart failure. Am J Cardiol 107(3), 433-438. doi: 10.1016/j.amjcard.2010.09.039.

Vaduganathan, M., Ambrosy, A.P., Greene, S.J., Mentz, R.J., Subacius, H.P., Maggioni, A.P., et al. (2012). Predictive value of low relative lymphocyte count in patients hospitalized for heart failure with reduced ejection fraction: insights from the EVEREST trial. Circ Heart Fail 5(6), 750-758. doi: 10.1161/CIRCHEARTFAILURE.112.970525.

Wang, B.L., Tian, L., Gao, X.H., Ma, X.L., Wu, J., Zhang, C.Y., et al. (2016). Dynamic change of the systemic immune inflammation index predicts the prognosis of patients with hepatocellular carcinoma after curative resection. Clin Chem Lab Med 54(12), 1963-1969. doi: 10.1515/cclm-2015-1191.

Xu, M., Zhang, L., Song, S., Pan, L., Muhammad Arslan, I., Chen, Y., et al. (2021). Hydrogen sulfide: Recent progress and perspectives for the treatment of dermatological diseases. $J A d v$ Res 27, 11-17. doi: 10.1016/j.jare.2020.02.003.

Yang, Y.L., Wu, C.H., Hsu, P.F., Chen, S.C., Huang, S.S., Chan, W.L., et al. (2020). Systemic immune-inflammation index (SII) predicted clinical outcome in patients with coronary artery disease. Eur J Clin Invest 50(5), e13230. doi: 10.1111/eci.13230.

Ye, G.L., Chen, Q., Chen, X., Liu, Y.Y., Yin, T.T., Meng, Q.H., et al. (2019). The prognostic role of platelet-to-lymphocyte ratio in patients with acute heart failure: A cohort study. Sci Rep 9(1), 10639. doi: 10.1038/s41598-019-47143-2. 
medRxiv preprint doi: https://doi.org/10.1101/2021.08.03.21261549; this version posted August 6, 2021. The copyright holder for this preprint (which was not certified by peer review) is the author/funder, who has granted medRxiv a license to display the preprint in perpetuity.

454 Figure 1. The non-linear curve fitting of the association between SII and 30- (A) and 90- (B) day allcause mortalities in critically ill patients with CHF after adjusting for age, gender, race, and other potential variables. SII, systemic immune-inflammation index. CHF, congestive heart failure.

A

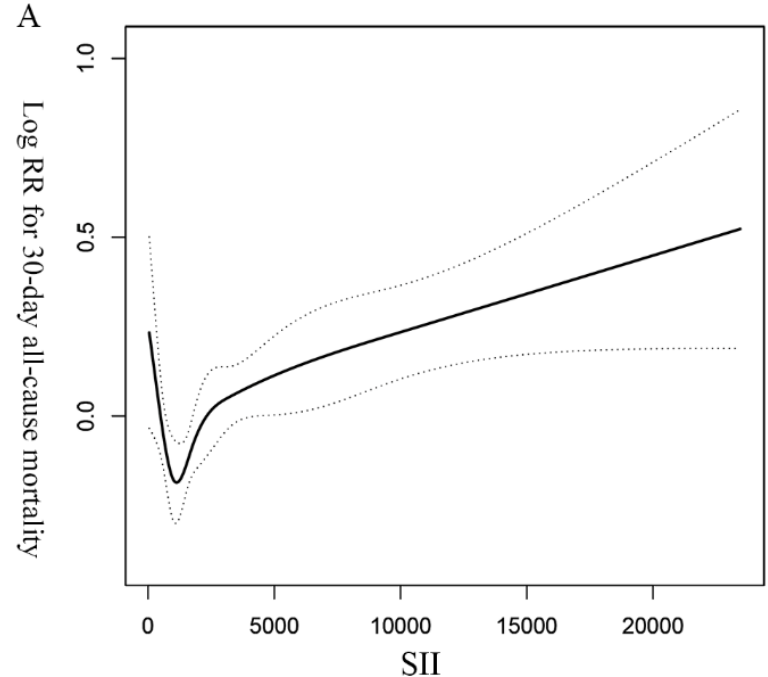

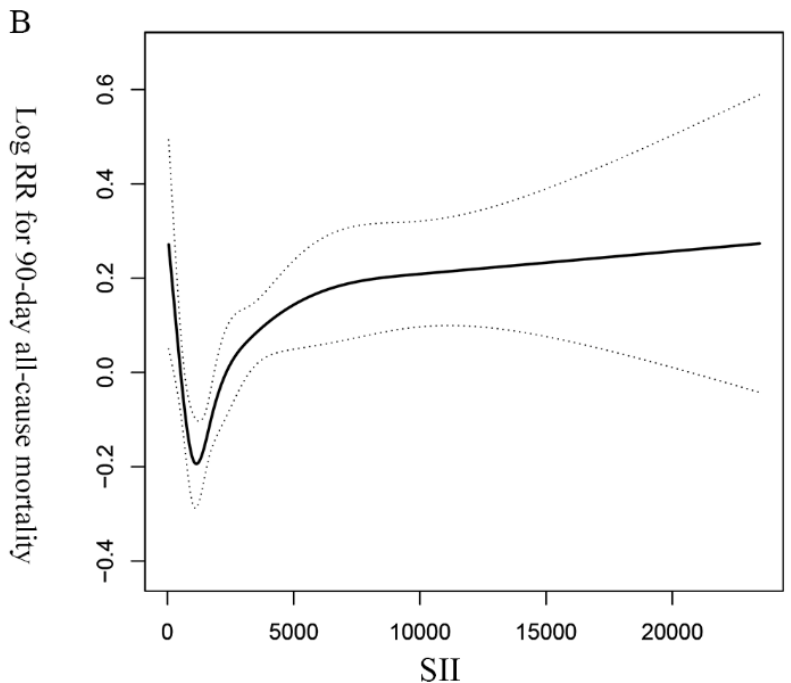

458 Figure 2. Kaplan-Meier survival curves showing the 30- (A) and 90- (B) day all-cause mortalities 459 stratified by SII tertile in critically ill patients with CHF. SII, systemic immune-inflammation index. 460 CHF, congestive heart failure.

A

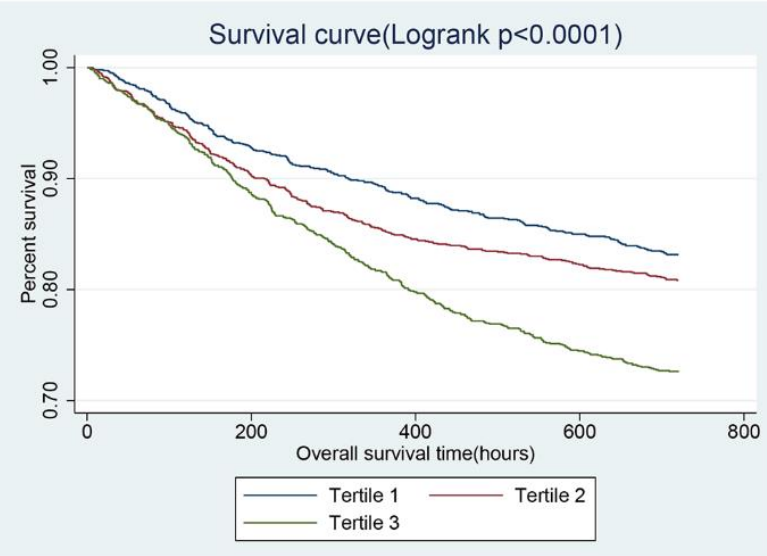

B

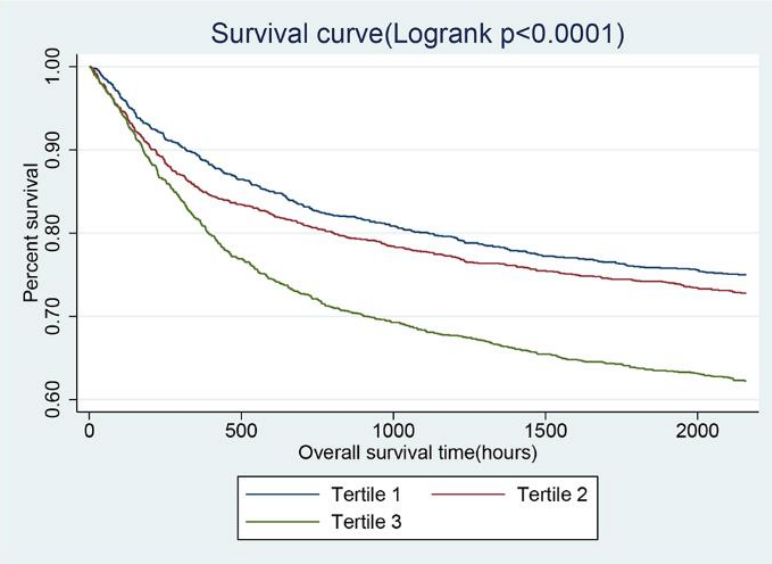

462 Figure 3. The histogram presenting the range of propensity scores and the corresponding number of 463 matches in high (red) and low (blue) SII groups. SII, systemic immune-inflammation index. 
medRxiv preprint doi: https://doi.org/10.1101/2021.08.03.21261549; this version posted August 6, 2021. The copyright holder for this preprint (which was not certified by peer review) is the author/funder, who has granted medRxiv a license to display the preprint in perpetuity.

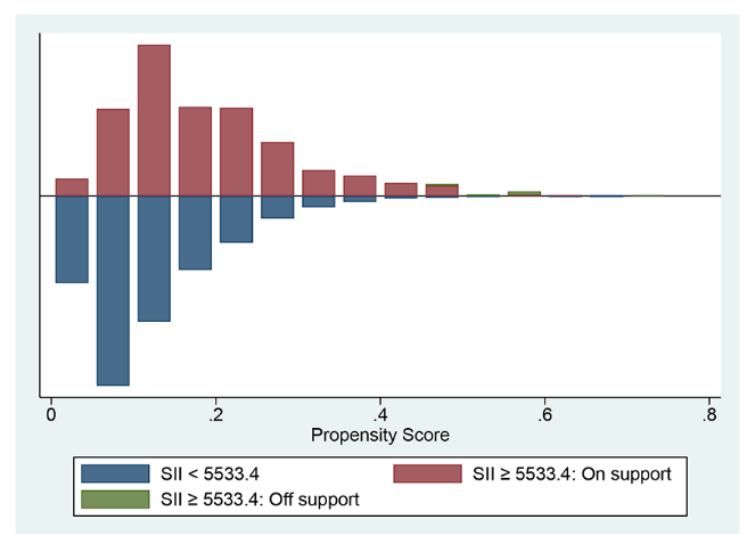

465 Figure 4. Kaplan-Meier survival curves showing the 30- (A) and 90- (B) day all-cause mortalities stratified by cut-off value of SII in critically ill patients with CHF before PSM. C and D presented the correlation between SII and 30- and 90-day mortalities after PSM, separately. SII, systemic immuneinflammation index. CHF, congestive heart failure. PSM, propensity score matching.

A

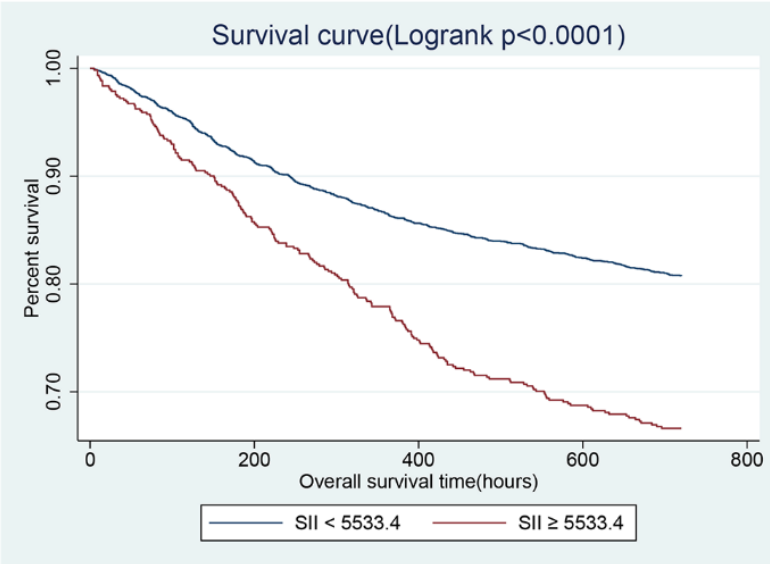

$\mathrm{C}$

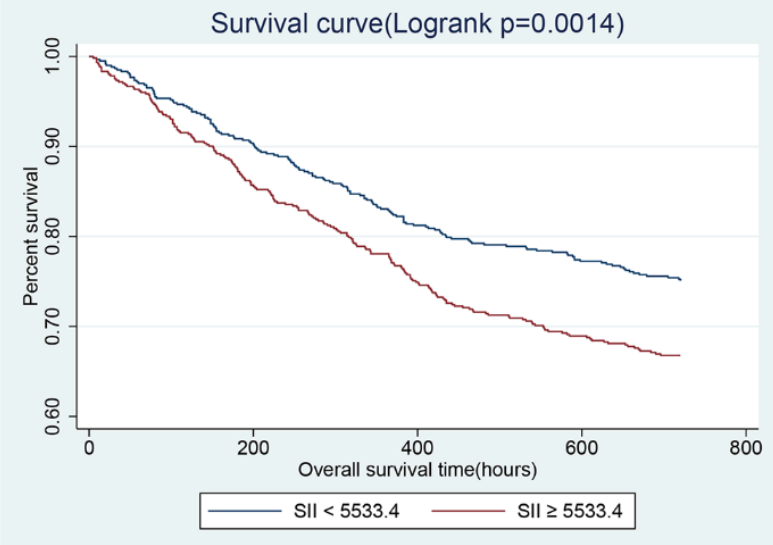

B

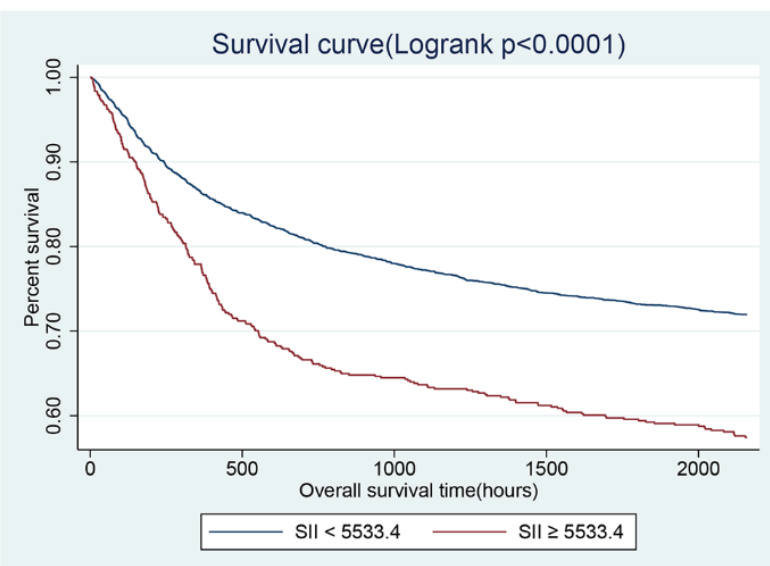

$\mathrm{D}$

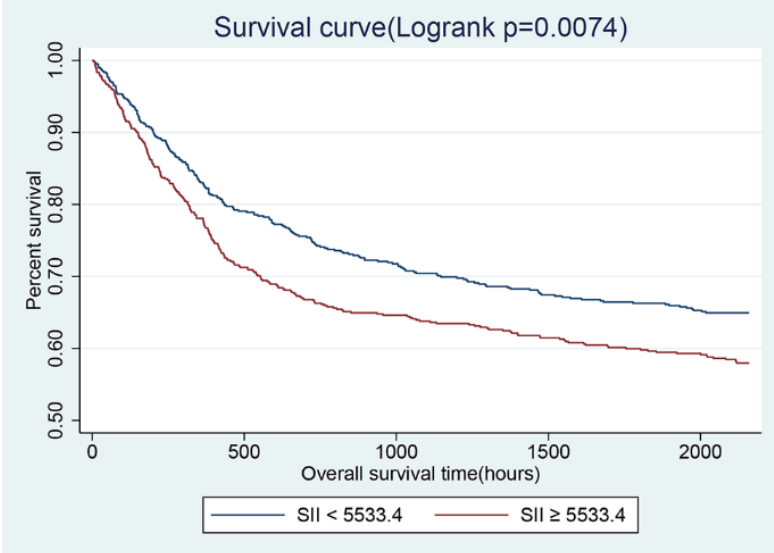

Figure 5. The forest plot showing the univariate (A) and multivariate (B) Cox regression for effects of SII on short-term mortality in the critically ill patients with CHF before and after PSM. SII, systemic immune-inflammation index. $\mathrm{CHF}$, congestive heart failure. PSM, propensity score matching. 
medRxiv preprint doi: https://doi.org/10.1101/2021.08.03.21261549; this version posted August 6, 2021. The copyright holder for this preprint (which was not certified by peer review) is the author/funder, who has granted medRxiv a license to display the preprint in perpetuity.

All rights reserved. No reuse allowed without permission.

SII in heart failure

A
Univariate analysis

Before PSM

30-day mortality

90-day mortality

Hospital mortality

After PSM

30-day mortality

90-day mortality

Hospital mortality

Before PSM

30-day mortality

90-day mortality

Hospital mortality

After PSM

30-day mortality

90-day mortality

Hospital mortality p value

474

475

476

477

478

479

480

481

482
$<0.0001$

$<0.0001$

$<0.0001$

$1.7299(1.4624,2.0463)$

$1.4108(1.1416,1.7435)$

$1.2829(1.0686,1.5402)$

0.0019

$1.4352(1.1423,1.8033)$

$p$ value

$\mathrm{HR}(95 \% \mathrm{Cl})$

$\mathrm{HR}(95 \% \mathrm{Cl})$

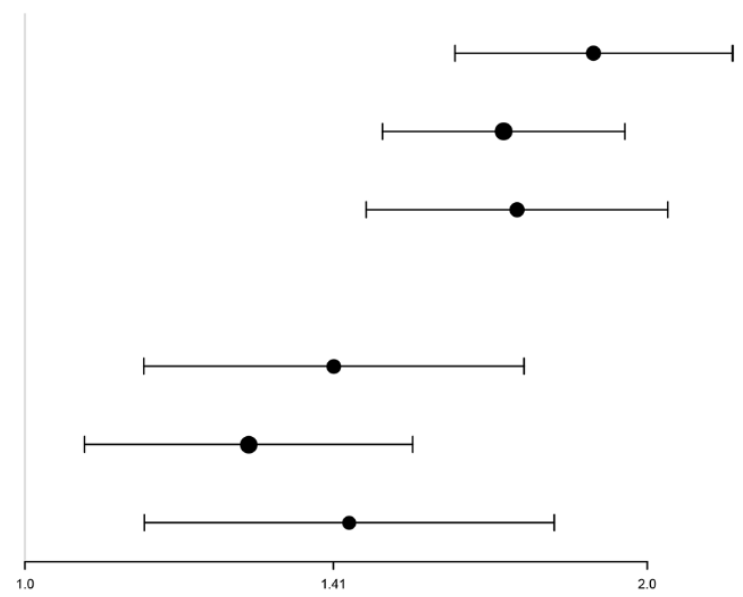

$\begin{array}{ll}<0.0001 & 1.3930(1.1887,1.6323) \\ 0.0003 & 1.2923(1.1254,1.4840) \\ 0.0004 & 1.3652(1.1486,1.6226)\end{array}$

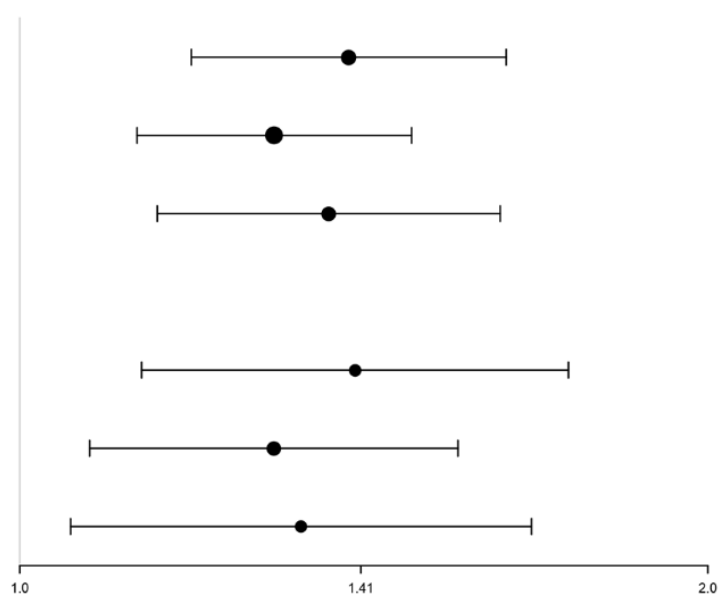

$0.0021 \quad 1.4018(1.1306,1.7380)$

$0.0068 \quad 1.2917(1.0730,1.5550)$

$0.0167 \quad 1.3276(1.0526,1.6745)$ 
medRxiv preprint doi: https://doi.org/10.1101/2021.08.03.21261549; this version posted August 6, 2021. The copyright holder for this preprint (which was not certified by peer review) is the author/funder, who has granted medRxiv a license to display the preprint in perpetuity.

All rights reserved. No reuse allowed without permission.

SII in heart failure

483 Table 1. The baseline clinical characteristics of critically ill patients with CHF.

\begin{tabular}{|c|c|c|c|c|}
\hline Parameter & $\operatorname{All}(n=4606)$ & $\begin{array}{l}\text { Survivors } \\
(n=3226)\end{array}$ & $\begin{array}{l}\text { Non-survivors } \\
(\mathbf{n = 1 3 8 0})\end{array}$ & $\begin{array}{l}p \\
\text { value }\end{array}$ \\
\hline \multicolumn{5}{|l|}{ Demographics } \\
\hline Age, years & $74.91(64.06-83.07)$ & $72.70(61.97-81.65)$ & $78.94(69.40-84.82)$ & $<0.001$ \\
\hline Male, n (\%) & $2436(52.89 \%)$ & $1690(52.39 \%)$ & $746(54.06 \%)$ & 0.298 \\
\hline Ethnicity, n (\%) & & & & $<0.001$ \\
\hline White & $3349(72.71 \%)$ & $2361(73.19 \%)$ & $988(71.59 \%)$ & \\
\hline Black & $332(7.21 \%)$ & $254(7.87 \%)$ & $78(5.65 \%)$ & \\
\hline Others & $925(20.08 \%)$ & $611(18.94 \%)$ & $314(22.75 \%)$ & \\
\hline \multicolumn{5}{|l|}{ Vital signs } \\
\hline HR, beats/minute & $85.02(74.53-96.54)$ & 84.33 (74.33-95.77) & 86.67 (75.24-98.65) & $<0.001$ \\
\hline $\mathrm{RR}$, times/minute & $19.42(16.87-22.38)$ & $19.17(16.76-21.91)$ & $20.03(17.24-23.45)$ & $<0.001$ \\
\hline $\mathrm{SBP}, \mathrm{mmHg}$ & $113.64(104.46-125.96)$ & $114.89(105.50-126.98)$ & $111.04(101.60-123.48)$ & $<0.001$ \\
\hline $\mathrm{DBP}, \mathrm{mmHg}$ & $56.93(50.87-63.71)$ & $57.85(51.64-64.34)$ & $55.10(49.46-61.64)$ & $<0.001$ \\
\hline Temperature, ${ }^{\circ} \mathrm{C}$ & $36.76(36.37-37.21)$ & $36.80(36.42-37.22)$ & $36.65(36.26-37.13)$ & $<0.001$ \\
\hline $\mathrm{SpO} 2, \%$ & 97.23 (95.74-98.46) & 97.25 (95.81-98.49) & $97.19(95.52-98.40)$ & 0.018 \\
\hline Weight, kg & 77.75 (64.70-93.60) & $79.80(65.60-96.00)$ & $73.80(62.00-88.00)$ & $<0.001$ \\
\hline \multicolumn{5}{|l|}{ Therapies, n (\%) } \\
\hline ACEI & $1266(27.49 \%)$ & $1012(31.37 \%)$ & $254(18.41 \%)$ & $<0.001$ \\
\hline ARB & $183(3.97 \%)$ & $151(4.68 \%)$ & $32(2.32 \%)$ & $<0.001$ \\
\hline$\beta$-blocker & $2827(61.38 \%)$ & $2074(64.29 \%)$ & $753(54.57 \%)$ & $<0.001$ \\
\hline Digoxin & $475(10.31 \%)$ & $303(9.39 \%)$ & $172(12.46 \%)$ & 0.002 \\
\hline Furosemide & $3190(69.26 \%)$ & $2275(70.52 \%)$ & $915(66.30 \%)$ & 0.004 \\
\hline Statins & $1451(31.50 \%)$ & $1121(34.75 \%)$ & $330(23.91 \%)$ & $<0.001$ \\
\hline Dialysis & $478(10.38 \%)$ & $278(8.62 \%)$ & $200(14.49 \%)$ & $<0.001$ \\
\hline Vasopressor & $1234(26.79 \%)$ & $727(22.54 \%)$ & $507(36.74 \%)$ & $<0.001$ \\
\hline Ventilation & $1879(40.79 \%)$ & $1133(35.12 \%)$ & $746(54.06 \%)$ & $<0.001$ \\
\hline Assisted circulation & $282(6.12 \%)$ & $186(5.77 \%)$ & $96(6.96 \%)$ & 0.123 \\
\hline
\end{tabular}


medRxiv preprint doi: https://doi.org/10.1101/2021.08.03.21261549; this version posted August 6, 2021. The copyright holder for this preprint (which was not certified by peer review) is the author/funder, who has granted medRxiv a license to display the preprint in perpetuity.

484 Table 1. Continued.

\begin{tabular}{|c|c|c|c|c|}
\hline Parameter & $\operatorname{All}(n=4606)$ & $\begin{array}{l}\text { Survivors } \\
(n=3226)\end{array}$ & $\begin{array}{l}\text { Non-survivors } \\
(\mathbf{n = 1 3 8 0})\end{array}$ & $\begin{array}{l}p \\
\text { value }\end{array}$ \\
\hline \multicolumn{5}{|l|}{ Laboratory events } \\
\hline Hemoglobin, g/dl & $10.90(9.70-12.30)$ & $11.10(9.80-12.50)$ & $10.70(9.40-11.90)$ & $<0.001$ \\
\hline Creatinine, $\mathrm{mg} / \mathrm{dl}$ & $1.20(0.90-1.80)$ & $1.20(0.90-1.70)$ & $1.30(0.90-2.10)$ & $<0.001$ \\
\hline BUN, mg/dl & $27.00(18.00-43.00)$ & $25.00(17.00-40.00)$ & $33.00(21.00-51.00)$ & $<0.001$ \\
\hline Glucose, $\mathrm{mg} / \mathrm{dl}$ & $135.33(115.00-166.12)$ & $134.23(115.47-164.03)$ & $137.71(114.36-170.52)$ & 0.111 \\
\hline Sodium, $\mathrm{mmol} / \mathrm{L}$ & $139.00(136.00-141.00)$ & $139.00(136.00-141.00)$ & $138.00(135.00-141.00)$ & 0.023 \\
\hline Potassium, mmol/L & $4.20(3.80-4.60)$ & $4.10(3.70-4.60)$ & $4.20(3.80-4.70)$ & 0.002 \\
\hline Chloride, $\mathrm{mmol} / \mathrm{L}$ & $103.00(99.00-107.00)$ & $103.00(99.25-107.00)$ & $103.00(99.00-107.00)$ & 0.035 \\
\hline Bicarbonate, $\mathrm{mmol} / \mathrm{L}$ & $24.00(21.00-28.00)$ & $25.00(22.00-28.00)$ & $24.00(20.00-27.00)$ & $<0.001$ \\
\hline PT, second & $14.30(13.20-16.80)$ & $14.20(13.10-16.50)$ & $14.80(13.40-17.90)$ & $<0.001$ \\
\hline APTT, second & $31.80(27.30-40.40)$ & $31.30(27.10-40.20)$ & $32.70(27.87-41.10)$ & 0.001 \\
\hline Lactate, $\mathrm{mmol} / \mathrm{L}$ & $1.82(1.30-2.90)$ & $1.80(1.20-2.83)$ & $2.00(1.30-3.00)$ & $<0.001$ \\
\hline Albumin, $\mathrm{g} / \mathrm{dL}$ & $3.00(2.56-3.40)$ & $3.00(2.60-3.42)$ & $2.89(2.45-3.24)$ & $<0.001$ \\
\hline Bilirubin, mg/dL & $1.40(0.60-3.05)$ & $1.40(0.60-3.00)$ & $1.41(0.60-3.10)$ & 0.339 \\
\hline ALT, IU/L & $60.00(22.00-298.33)$ & $69.00(23.92-327.15)$ & $45.00(19.00-207.75)$ & $<0.001$ \\
\hline NT-proBNP, ng/ml & $10.98(4.67-18.83)$ & $10.70(4.26-18.34)$ & $11.91(5.67-19.96)$ & $<0.001$ \\
\hline cTnT, ng/mL & $1.34(0.10-2.87)$ & $1.46(0.11-2.94)$ & $1.12(0.09-2.58)$ & $<0.001$ \\
\hline $\mathrm{CI}, \mathrm{L} / \mathrm{min} / \mathrm{m}^{2}$ & $2.76(2.13-3.47)$ & $2.75(2.13-3.48)$ & $2.78(2.14-3.45)$ & 0.626 \\
\hline Urine output, L & $1.54(0.89-2.44)$ & $1.73(1.02-2.65)$ & $1.14(0.67-1.87)$ & $<0.001$ \\
\hline $\mathrm{SII} \times 10$ & $174.76(92.24-344.55)$ & $163.11(88.62-309.02)$ & $213.97(105.80-430.34)$ & $<0.001$ \\
\hline Hospitalization type & & & & $<0.001$ \\
\hline Emergency, n (\%) & $4062(88.19 \%)$ & $2804(86.92 \%)$ & $1258(91.16 \%)$ & \\
\hline Elective, n (\%) & $367(7.97 \%)$ & $300(9.30 \%)$ & $67(4.86 \%)$ & \\
\hline First ICU admission & & & & $<0.001$ \\
\hline $\mathrm{CCU}, \mathrm{n}(\%)$ & $1236(26.83 \%)$ & $898(27.84 \%)$ & $338(24.49 \%)$ & \\
\hline MICU, n (\%) & $2005(43.53 \%)$ & $1308(40.55 \%)$ & $697(50.51 \%)$ & \\
\hline
\end{tabular}


medRxiv preprint doi: https://doi.org/10.1101/2021.08.03.21261549; this version posted August 6, 2021. The copyright holder for this preprint

(which was not certified by peer review) is the author/funder, who has granted medRxiv a license to display the preprint in perpetuity.

Table 1. Continued.

\begin{tabular}{|c|c|c|c|c|}
\hline Parameter & $\operatorname{All}(n=4606)$ & $\begin{array}{l}\text { Survivors } \\
(\mathrm{n}=3226)\end{array}$ & $\begin{array}{l}\text { Non-survivors } \\
(n=1380)\end{array}$ & $\begin{array}{l}p \\
\text { value }\end{array}$ \\
\hline \multicolumn{5}{|l|}{ Comorbidities, n (\%) } \\
\hline Hypertension & $937(20.34 \%)$ & $655(20.30 \%)$ & $282(20.43 \%)$ & 0.919 \\
\hline Hyperlipemia & $1260(27.36 \%)$ & $975(30.22 \%)$ & $285(20.65 \%)$ & $<0.001$ \\
\hline Diabetes mellitus & $1657(35.97 \%)$ & $1218(37.76 \%)$ & $439(31.81 \%)$ & $<0.001$ \\
\hline Atrial fibrillation & $2077(45.09 \%)$ & $1361(42.19 \%)$ & $716(51.88 \%)$ & $<0.001$ \\
\hline AMI & $346(7.51 \%)$ & $241(7.47 \%)$ & $105(7.61 \%)$ & 0.871 \\
\hline VHD & $463(10.05 \%)$ & $289(8.96 \%)$ & $174(12.61 \%)$ & $<0.001$ \\
\hline Peripheral vascular & $577(12.53 \%)$ & $397(12.31 \%)$ & $180(13.04 \%)$ & 0.489 \\
\hline Pulmonary circulation & $292(6.34 \%)$ & $183(5.67 \%)$ & $109(7.90 \%)$ & 0.005 \\
\hline Pneumonia & $1350(29.31 \%)$ & $858(26.60 \%)$ & $492(35.65 \%)$ & $<0.001$ \\
\hline COPD & $245(5.32 \%)$ & $156(4.84 \%)$ & $89(6.45 \%)$ & 0.025 \\
\hline Liver diseases & $232(5.04 \%)$ & $138(4.28 \%)$ & $94(6.81 \%)$ & $<0.001$ \\
\hline Renal failure & $1120(24.32 \%)$ & $757(23.47 \%)$ & $363(26.30 \%)$ & 0.040 \\
\hline Stroke & $250(5.43 \%)$ & $148(4.59 \%)$ & $102(7.39 \%)$ & $<0.001$ \\
\hline Hypothyroidism & $555(12.05 \%)$ & $392(12.15 \%)$ & $163(11.81 \%)$ & 0.746 \\
\hline Malignancy & $253(5.49 \%)$ & $128(3.97 \%)$ & $125(9.06 \%)$ & $<0.001$ \\
\hline Depression & $359(7.79 \%)$ & $276(8.56 \%)$ & $83(6.01 \%)$ & 0.003 \\
\hline \multicolumn{5}{|l|}{ Scores } \\
\hline SOFA & $5.00(3.00-7.00)$ & $4.00(3.00-6.00)$ & $6.00(4.00-8.00)$ & $<0.001$ \\
\hline SAPSII & $40.00(32.00-49.00)$ & $38.00(30.00-46.00)$ & $47.00(39.00-56.00)$ & $<0.001$ \\
\hline Length of ICU stay, h & $94.00(50.00-187.00)$ & $88.00(48.00-166.75)$ & $122.00(62.00-240.25)$ & $<0.001$ \\
\hline
\end{tabular}

Abbreviations: $\mathrm{HR}$, heart rate; $\mathrm{RR}$, respiratory rate; SBP, systolic blood pressure; $\mathrm{DBP}$, diastolic blood pressure; $\mathrm{SpO} 2$, percutaneous oxygen saturation; ACEI, angiotensin-converting enzyme inhibitors; ARB, angiotensin receptor blockers; BUN, blood urea nitrogen; PT, prothrombin time; APTT, activated partial thromboplastin time; ALT, alanine transaminase; cTnT, troponin T; NTproBNP, N-terminal pro brain natriuretic peptide; CI, cardiac index; SII, Systemic immune- 
medRxiv preprint doi: https://doi.org/10.1101/2021.08.03.21261549; this version posted August 6, 2021. The copyright holder for this preprint

(which was not certified by peer review) is the author/funder, who has granted medRxiv a license to display the preprint in perpetuity.

All rights reserved. No reuse allowed without permission.

SII in heart failure

494 Table 2. The univariate and multivariate Cox regression analysis exploring the association of SII

495 tertile with short-term mortality of critically ill patients with CHF.

\begin{tabular}{|c|c|c|c|c|c|c|}
\hline & \multicolumn{2}{|l|}{ Crude } & \multicolumn{2}{|l|}{ Model I } & \multicolumn{2}{|l|}{ Model II } \\
\hline & HR (95\% CIs) & $P$ value & HR (95\% CIs) & $P$ value & HR (95\% CIs) & $P$ value \\
\hline \multicolumn{7}{|l|}{ 30-day all-cause mortality } \\
\hline SII & $1.00(1.00,1.00)$ & $<0.001$ & $1.00(1.00,1.00)$ & $<0.0001$ & $1.00(1.00,1.00)$ & $<0.0001$ \\
\hline \multicolumn{7}{|l|}{ SII (tertile) } \\
\hline$<1144.28$ & 1 (ref) & & 1 (ref) & & 1 (ref) & \\
\hline$\geqslant 1144.28,<2730.11$ & $1.17(0.99,1.38)$ & 0.067 & $1.14(0.97,1.35)$ & 0.112 & $1.05(0.89,1.25)$ & 0.524 \\
\hline$\geqslant 2730.11$ & $1.73(1.48,2.03)$ & $<0.001$ & $1.63(1.40,1.91)$ & $<0.001$ & $1.23(1.04,1.45)$ & 0.011 \\
\hline$P$ for trend & $<0.001$ & & $<0.001$ & & $<0.001$ & \\
\hline \multicolumn{7}{|l|}{ 90-day all-cause mortality } \\
\hline SII & $1.00(1.00,1.00)$ & $<0.001$ & $1.00(1.00,1.00)$ & $<0.0001$ & $1.00(1.00,1.00)$ & 0.001 \\
\hline \multicolumn{7}{|l|}{ SII (tertile) } \\
\hline$<1144.28$ & 1 (ref) & & 1 (ref) & & 1 (ref) & \\
\hline$\geqslant 1144.28,<2730.11$ & $1.12(0.97,1.28)$ & 0.114 & $1.10(0.96,1.27)$ & 0.168 & $1.02(0.88,1.17)$ & 0.820 \\
\hline$\geqslant 2730.11$ & $1.65(1.45,1.88)$ & $<0.001$ & $1.57(1.38,1.79)$ & $<0.001$ & $1.21(1.06,1.39)$ & 0.005 \\
\hline$P$ for trend & $<0.001$ & & $<0.001$ & & $<0.001$ & \\
\hline \multicolumn{7}{|l|}{ Hospital all-cause mortality } \\
\hline SII & $1.00(1.00,1.00)$ & $<0.001$ & $1.00(1.00,1.00)$ & $<0.0001$ & $1.00(1.00,1.00)$ & 0.002 \\
\hline \multicolumn{7}{|l|}{ SII (tertile) } \\
\hline$<1144.28$ & 1 (ref) & & 1 (ref) & & 1 (ref) & \\
\hline$\geqslant 1144.28,<2730.11$ & $1.27(1.06,1.52)$ & 0.008 & $1.21(1.01,1.45)$ & 0.035 & $1.17(0.97,1.40)$ & 0.096 \\
\hline$\geqslant 2730.11$ & $1.61(1.36,1.91)$ & $<0.001$ & $1.45(1.22,1.72)$ & $<0.001$ & $1.26(1.05,1.50)$ & 0.011 \\
\hline$P$ for trend & $<0.001$ & & $<0.001$ & & $<0.001$ & \\
\hline
\end{tabular}

496 Crude model was adjusted for none.

497 Model I was adjusted for age, gender, and race.

498 Model II was adjusted for age, gender, race, heart rate, blood urea nitrogen, albumin, troponin T, NT-

499 proBNP, urine output of first day, cardiac index, the type of first ICU admission, the use of

500 mechanical ventilation and vasopressor, pneumonia, and liver diseases.

501 Abbreviations: SII, Systemic immune-inflammation index; CHF, congestive heart failure; HR,

502 hazard ratio; $\mathrm{CI}$, confidence interval. 
medRxiv preprint doi: https://doi.org/10.1101/2021.08.03.21261549; this version posted August 6, 2021. The copyright holder for this preprint (which was not certified by peer review) is the author/funder, who has granted medRxiv a license to display the preprint in perpetuity.

All rights reserved. No reuse allowed without permission.

SII in heart failure

503 Table 3. The univariate and multivariate Logistic regression analysis exploring the association of SII

504 tertile with readmission and MACEs of critically ill patients with CHF.

\begin{tabular}{|c|c|c|c|c|c|c|}
\hline & \multicolumn{2}{|l|}{ Crude } & \multicolumn{2}{|l|}{ Model I } & \multicolumn{2}{|l|}{ Model II } \\
\hline & OR (95\% CIs) & $P$ value & OR (95\% CIs) & $P$ value & OR (95\% CIs) & $P$ value \\
\hline \multicolumn{7}{|l|}{ Readmission } \\
\hline \multicolumn{7}{|l|}{ SII (tertile) } \\
\hline$<1144.28$ & $1(\mathrm{ref})$ & & 1 (ref) & & 1 (ref) & \\
\hline$\geqslant 1144.28,<2730.11$ & $0.91(0.77,1.07)$ & 0.253 & $0.94(0.80,1.11)$ & 0.472 & $0.94(0.80,1.11)$ & 0.484 \\
\hline$\geqslant 2730.11$ & $0.88(0.75,1.04)$ & 0.129 & $0.93(0.78,1.10)$ & 0.392 & $0.97(0.81,1.15)$ & 0.703 \\
\hline$P$ for trend & $<0.001$ & & $<0.001$ & & $<0.001$ & \\
\hline \multicolumn{7}{|l|}{ MACEs } \\
\hline \multicolumn{7}{|l|}{ SII (tertile) } \\
\hline$<1144.28$ & 1 (ref) & & 1 (ref) & & 1 (ref) & \\
\hline$\geqslant 1144.28,<2730.11$ & $1.17(1.02,1.35)$ & 0.030 & $1.17(1.02,1.35)$ & 0.028 & $0.92(0.74,1.13)$ & 0.417 \\
\hline$\geqslant 2730.11$ & $2.01(1.73,2.32)$ & $<0.001$ & $2.02(1.74,2.35)$ & $<0.001$ & $1.39(1.12,1.73)$ & 0.003 \\
\hline$P$ for trend & $<0.001$ & & $<0.001$ & & $<0.001$ & \\
\hline
\end{tabular}

505 Crude model was adjusted for none.

506 Model I was adjusted for age, gender, and race.

507 Model II was adjusted for age, gender, race, heart rate, blood urea nitrogen, albumin, troponin T, NT-

508 proBNP, urine output of first day, cardiac index, the type of first ICU admission, the use of

509 mechanical ventilation and vasopressor, pneumonia, and liver diseases.

510 Abbreviations: SII, Systemic immune-inflammation index; CHF, congestive heart failure; HR,

511 hazard ratio; CI, confidence interval.

512

513

514

515

516

517

518

519 
medRxiv preprint doi: https://doi.org/10.1101/2021.08.03.21261549; this version posted August 6, 2021. The copyright holder for this preprint (which was not certified by peer review) is the author/funder, who has granted medRxiv a license to display the preprint in perpetuity.

All rights reserved. No reuse allowed without permission.

SII in heart failure

520 Table 4. Subgroup analysis of the relationship between SII and 30-day all-cause mortality.

\begin{tabular}{|c|c|c|c|c|c|}
\hline & \multirow{2}{*}{$\mathbf{N}$} & \multicolumn{3}{|c|}{ SII } & \multirow{2}{*}{$\begin{array}{l}P \text { for } \\
\text { interaction }\end{array}$} \\
\hline & & $<1144.28$ & $\geqslant 1144.28,<2730.11$ & $\geqslant 2730.11$ & \\
\hline Hypertension & & & & & 0.178 \\
\hline No & 3669 & 1.0 (ref) & $1.09(0.90,1.31)$ & $1.70(1.44,2.02)$ & \\
\hline Yes & 937 & 1.0 (ref) & $1.57(1.07,2.31)$ & $1.88(1.28,2.76)$ & \\
\hline Diabetes & & & & & 0.384 \\
\hline No & 2949 & 1.0 (ref) & $1.16(0.95,1.42)$ & $1.62(1.34,1.95)$ & \\
\hline Yes & 1657 & 1.0 (ref) & $1.22(0.90,1.65)$ & $2.01(1.52,2.67)$ & \\
\hline Hyperlipemia & & & & & 0.006 \\
\hline No & 3346 & 1.0 (ref) & $1.13(0.94,1.36)$ & $1.51(1.27,1.80)$ & \\
\hline Yes & 1260 & 1.0 (ref) & $1.40(0.96,2.05)$ & $2.77(1.94,3.96)$ & \\
\hline AMI & & & & & 0.016 \\
\hline No & 4260 & 1.0 (ref) & $1.09(0.92,1.30)$ & $1.71(1.46,2.01)$ & \\
\hline Yes & 346 & 1.0 (ref) & $2.63(1.30,5.30)$ & $2.31(1.14,4.69)$ & \\
\hline VHD & & & & & 0.602 \\
\hline No & 4143 & 1.0 (ref) & $1.15(0.96,1.38)$ & $1.76(1.49,2.07)$ & \\
\hline Yes & 463 & 1.0 (ref) & $1.23(0.76,2.00)$ & $1.50(0.94,2.41)$ & \\
\hline PCD & & & & & 0.931 \\
\hline No & 4314 & 1.0 (ref) & $1.17(0.98,1.39)$ & $1.72(1.46,2.02)$ & \\
\hline Yes & 292 & 1.0 (ref) & $1.15(0.61,2.19)$ & $1.86(1.05,3.32)$ & \\
\hline Atrial fibrillation & & & & & 0.437 \\
\hline No & 2529 & 1.0 (ref) & $1.04(0.82,1.31)$ & $1.59(1.28,1.98)$ & \\
\hline Yes & 2077 & 1.0 (ref) & $1.29(1.02,1.64)$ & $1.84(1.47,2.31)$ & \\
\hline Pneumonia & & & & & 0.061 \\
\hline No & 3256 & 1.0 (ref) & $1.18(0.96,1.44)$ & $1.89(1.56,2.29)$ & \\
\hline Yes & 1350 & 1.0 (ref) & $1.09(0.82,1.45)$ & $1.33(1.03,1.74)$ & \\
\hline COPD & & & & & 0.962 \\
\hline No & 4361 & 1.0 (ref) & $1.16(0.98,1.38)$ & $1.72(1.47,2.02)$ & \\
\hline Yes & 245 & 1.0 (ref) & $1.32(0.54,3.20)$ & $1.86(0.83,4.17)$ & \\
\hline Liver diseases & & & & & 0.065 \\
\hline No & 4374 & 1.0 (ref) & $1.26(1.06,1.50)$ & $1.85(1.57,2.18)$ & \\
\hline Yes & 232 & 1.0 (ref) & $0.62(0.34,1.13)$ & $1.24(0.70,2.21)$ & \\
\hline
\end{tabular}


medRxiv preprint doi: https://doi.org/10.1101/2021.08.03.21261549; this version posted August 6, 2021. The copyright holder for this preprint (which was not certified by peer review) is the author/funder, who has granted medRxiv a license to display the preprint in perpetuity.

All rights reserved. No reuse allowed without permission.

SII in heart failure

521 Table 4. Continued.

\begin{tabular}{|c|c|c|c|c|c|}
\hline & \multirow[t]{2}{*}{$\mathbf{N}$} & \multicolumn{3}{|c|}{ SII } & \multirow{2}{*}{$\begin{array}{l}P \text { for } \\
\text { interaction }\end{array}$} \\
\hline & & $<1144.28$ & $\geqslant 1144.28,<2730.11$ & $\geqslant 2730.11$ & \\
\hline Renal failure & & & & & 0.396 \\
\hline No & 3486 & 1.0 (ref) & $1.10(0.91,1.33)$ & $1.72(1.44,2.05)$ & \\
\hline Yes & 1120 & 1.0 (ref) & $1.39(1.00,1.94)$ & $1.79(1.30,2.48)$ & \\
\hline Hypothyroidism & & & & & 0.628 \\
\hline No & 4051 & 1.0 (ref) & $1.13(0.95,1.35)$ & $1.71(1.45,2.01)$ & \\
\hline Yes & 555 & 1.0 (ref) & $1.46(0.90,2.38)$ & $1.96(1.23,3.12)$ & \\
\hline Stroke & & & & & 0.618 \\
\hline No & 4356 & $1.0(\mathrm{ref})$ & $1.14(0.96,1.36)$ & $1.69(1.44,1.99)$ & \\
\hline Yes & 250 & 1.0 (ref) & $1.45(0.79,2.65)$ & $2.24(1.26,3.97)$ & \\
\hline Depression & & & & & 0.216 \\
\hline No & 4247 & 1.0 (ref) & $1.17(0.98,1.39)$ & $1.79(1.52,2.10)$ & \\
\hline Yes & 359 & 1.0 (ref) & $1.11(0.55,2.25)$ & $1.02(0.51,2.03)$ & \\
\hline Malignancy & & & & & 0.879 \\
\hline No & 4353 & 1.0 (ref) & $1.18(0.99,1.40)$ & $1.72(1.46,2.02)$ & \\
\hline Yes & 253 & 1.0 (ref) & $1.02(0.57,1.83)$ & $1.57(0.94,2.63)$ & \\
\hline SOFA & & & & & 0.172 \\
\hline$<5$ & 2149 & 1.0 (ref) & $1.24(0.91,1.70)$ & $2.21(1.66,2.96)$ & \\
\hline$\geqslant 5$ & 2457 & 1.0 (ref) & $1.20(0.99,1.46)$ & $1.58(1.31,1.90)$ & \\
\hline SAPSII & & & & & 0.255 \\
\hline$<40$ & 2181 & 1.0 (ref) & $1.22(0.87,1.71)$ & $1.99(1.43,2.75)$ & \\
\hline$\geqslant 40$ & 2425 & $1.0(\mathrm{ref})$ & $1.13(0.93,1.37)$ & $1.42(1.19,1.69)$ & \\
\hline
\end{tabular}

Abbreviations: SII, Systemic immune-inflammation index; AMI, acute myocardial infarction; VHD, 523 valvular heart disease; PCD, peripheral vascular diseases; COPD, chronic obstructive pulmonary 524 disease. 
medRxiv preprint doi: https://doi.org/10.1101/2021.08.03.21261549; this version posted August 6, 2021. The copyright holder for this preprint

(which was not certified by peer review) is the author/funder, who has granted medRxiv a license to display the preprint in perpetuity.

All rights reserved. No reuse allowed without permission.

SII in heart failure

530 Table 5. The clinical characteristics in critically ill patients with CHF before and after PSM.

\begin{tabular}{|c|c|c|c|c|c|c|}
\hline \multirow{2}{*}{ Parameter } & \multicolumn{3}{|c|}{ Before PSM } & \multicolumn{3}{|c|}{ After PSM } \\
\hline & $<5533.4$ & $\geqslant 5533.4$ & $P$ value & $<5533.4$ & $\geqslant 5533.4$ & $P$ value \\
\hline $\mathbf{N}$ & 3995 & 611 & & 602 & 602 & 602 \\
\hline \multicolumn{7}{|l|}{ Demographics } \\
\hline Age, years & $74.4(63.4-82.9)$ & $76.9(68.2-83.7)$ & $<0.001$ & $77.7(66.1-84.2)$ & $76.9(68.1-83.7)$ & 0.984 \\
\hline Male, n (\%) & $2154(53.9 \%)$ & $282(46.2 \%)$ & $<0.001$ & $279(46.3 \%)$ & $279(46.3 \%)$ & 1.000 \\
\hline Ethnicity, n (\%) & & 0.001 & 0.001 & & & 0.526 \\
\hline White & $2879(72.1 \%)$ & $470(76.9 \%)$ & & $463(76.9 \%)$ & $461(76.6 \%)$ & \\
\hline Black & $309(7.7 \%)$ & $23(3.8 \%)$ & & $30(5.0 \%)$ & $23(3.8 \%)$ & \\
\hline Others & $807(20.2 \%)$ & $118(19.3 \%)$ & & $109(18.1 \%)$ & $118(19.6 \%)$ & \\
\hline \multicolumn{7}{|l|}{ Vital signs } \\
\hline HR, beats/minute & $84.5(74.1-96.0)$ & $88.2(77.0-99.6)$ & $<0.001$ & $87.5(77.3-98.8)$ & $87.9(76.8-99.2)$ & 0.840 \\
\hline $\mathrm{RR}$, times/minute & $19.3(16.8-22.3)$ & $20.3(17.6-23.2)$ & $<0.001$ & $20.2(17.3-23.5)$ & $20.2(17.6-23.1)$ & 0.876 \\
\hline SBP, mmHg & $113.8(104.6-126.0)$ & $113.8(104.6-126.0)$ & 0.145 & $113.9(103.4-125.6)$ & $112.1(103.5-125.7)$ & 0.964 \\
\hline DBP, mmHg & $57.1(51.1-63.9)$ & $55.7(50.2-62.5)$ & 0.009 & $55.3(49.1-61.9)$ & $55.6(50.2-62.5)$ & 0.219 \\
\hline Temperature, ${ }^{\circ} \mathrm{C}$ & $36.8(36.4-37.2)$ & $36.7(36.3-37.1)$ & 0.010 & $36.8(36.4-37.2)$ & $36.7(36.3-37.1)$ & 0.254 \\
\hline $\mathrm{SpO} 2, \%$ & $97.3(95.8-98.5)$ & $97.0(95.5-98.4)$ & 0.157 & $97.3(95.6-98.5)$ & $97.0(95.5-98.4)$ & 0.474 \\
\hline Weight, $\mathrm{kg}$ & $78.4(65.0-94.3)$ & $74.4(61.0-90.0)$ & $<0.001$ & $73.0(61.0-88.5)$ & $74.4(61.0-90.0)$ & 0.560 \\
\hline \multicolumn{7}{|l|}{ Therapies, n (\%) } \\
\hline ACEI & $1117(28.0 \%)$ & $149(24.4 \%)$ & 0.065 & $153(25.4 \%)$ & $147(24.4 \%)$ & 0.689 \\
\hline ARB & $158(4.0 \%)$ & $25(4.1 \%)$ & 0.872 & $26(4.3 \%)$ & $25(4.2 \%)$ & 0.886 \\
\hline$\beta$-blocker & $2454(61.4 \%)$ & $373(61.0 \%)$ & 0.858 & $373(62.0 \%)$ & $367(61.0 \%)$ & 0.722 \\
\hline Digoxin & $411(10.3 \%)$ & $64(10.5 \%)$ & 0.888 & $85(14.1 \%)$ & $63(10.5 \%)$ & 0.053 \\
\hline Furosemide & $2766(69.2 \%)$ & $424(69.4 \%)$ & 0.937 & $412(68.4 \%)$ & $416(69.1 \%)$ & 0.804 \\
\hline Statins & $1274(31.9 \%)$ & $177(29.0 \%)$ & 0.148 & $158(26.2 \%)$ & $174(28.9 \%)$ & 0.302 \\
\hline Dialysis & $426(10.7 \%)$ & $52(8.5 \%)$ & 0.104 & $86(14.3 \%)$ & $51(8.5 \%)$ & 0.001 \\
\hline Vasopressor & $1042(26.1 \%)$ & $192(31.4 \%)$ & 0.008 & $171(28.4 \%)$ & $187(31.1 \%)$ & 0.313 \\
\hline Ventilation & $1561(39.1 \%)$ & $318(52.0 \%)$ & $<0.001$ & $306(50.8 \%)$ & $310(51.5 \%)$ & 0.818 \\
\hline Assisted circulation & $259(6.5 \%)$ & $23(3.8 \%)$ & 0.009 & $21(3.5 \%)$ & $23(3.8 \%)$ & 0.759 \\
\hline \multicolumn{7}{|l|}{ Scores } \\
\hline SOFA & $5.0(3.0-7.0)$ & $5.0(3.0-7.0)$ & 0.556 & $5.0(3.0-7.0)$ & $5.0(3.0-7.0)$ & 0.405 \\
\hline SAPSII & $40.0(32.0-49.0)$ & $45.0(36.0-53.5)$ & $<0.001$ & $44.0(35.0-53.0)$ & $45.0(36.0-53.0)$ & 0.440 \\
\hline
\end{tabular}


medRxiv preprint doi: https://doi.org/10.1101/2021.08.03.21261549; this version posted August 6, 2021. The copyright holder for this preprint

(which was not certified by peer review) is the author/funder, who has granted medRxiv a license to display the preprint in perpetuity.

All rights reserved. No reuse allowed without permission.

SII in heart failure

531 Table 5. Continued.

\begin{tabular}{|c|c|c|c|c|c|c|}
\hline \multirow{2}{*}{ Parameter } & \multicolumn{3}{|c|}{ Before PSM } & \multicolumn{3}{|c|}{ After PSM } \\
\hline & $<5533.4$ & $\geqslant 5533.4$ & $P$ value & $<5533.4$ & $\geqslant 5533.4$ & $P$ value \\
\hline $\mathbf{N}$ & 3995 & 611 & & 602 & 602 & \\
\hline \multicolumn{7}{|l|}{ Laboratory events } \\
\hline Hemoglobin, $\mathrm{g} / \mathrm{dl}$ & $11.0(9.7-12.4)$ & $10.7(9.5-12.1)$ & 0.008 & $10.7(9.5-11.9)$ & $10.7(9.5-12.1)$ & 0.290 \\
\hline Creatinine, $\mathrm{mg} / \mathrm{dl}$ & $1.2(0.9-1.8)$ & $1.2(0.9-2.1)$ & 0.250 & $1.3(0.9-2.0)$ & $1.2(0.9-2.1)$ & 0.160 \\
\hline BUN, mg/dl & $26.0(18.0-42.0)$ & $30.0(19.0-49.0)$ & $<0.001$ & $31.0(20.0-49.0)$ & $30.0(19.0-48.0)$ & 0.613 \\
\hline Glucose, mg/dl & $134.0(114.4-163.6)$ & $145.5(119.7-176.8)$ & $<0.001$ & $141.2(117.1-180.3)$ & $145.5(119.6-176.2)$ & 0.610 \\
\hline Sodium, $\mathrm{mmol} / \mathrm{L}$ & $139.0(136.0-141.0)$ & $138.0(135.0-141.0)$ & $<0.001$ & $138.0(135.0-141.0)$ & $138.0(135.0-141.0)$ & 0.487 \\
\hline Potassium, mmol/L & $4.2(3.8-4.6)$ & $4.2(3.7-4.7)$ & 0.575 & $4.2(3.8-4.7)$ & $4.2(3.7-4.7)$ & 0.634 \\
\hline Chloride, $\mathrm{mmol} / \mathrm{L}$ & $103.0(100.0-107.0)$ & $102.0(98.0-107.0)$ & $<0.001$ & $103.0(99.0-106.0)$ & $102.0(98.0-107.0)$ & 0.377 \\
\hline Bicarbonate, $\mathrm{mmol} / \mathrm{L}$ & $25.0(21.0-28.0)$ & $24.0(20.0-27.0)$ & $<0.001$ & $24.0(20.0-27.0)$ & $24.0(20.0-27.0)$ & 0.878 \\
\hline PT, second & $14.3(13.2-16.8)$ & $14.4(13.2-17.1)$ & 0.245 & $14.4(13.2-17.3)$ & $14.4(13.2-17.2)$ & 0.846 \\
\hline APTT, second & $31.8(27.3-41.1)$ & $31.6(27.3-38.6)$ & 0.329 & $31.3(27.3-40.2)$ & $31.7(27.3-38.7)$ & 0.920 \\
\hline Lactate, $\mathrm{mmol} / \mathrm{L}$ & $1.9(1.3-2.9)$ & $1.8(1.3-2.8)$ & 0.654 & $1.8(1.3-3.0)$ & $1.8(1.3-2.8)$ & 0.654 \\
\hline Albumin, $\mathrm{g} / \mathrm{dL}$ & $3.0(2.6-3.4)$ & $2.9(2.5-3.3)$ & $<0.001$ & $2.8(2.4-3.3)$ & $2.9(2.5-3.3)$ & 0.255 \\
\hline Bilirubin, mg/dL & $1.5(0.6-3.1)$ & $0.9(0.4-2.5)$ & $<0.001$ & $1.1(0.5-2.4)$ & $0.9(0.4-2.6)$ & 0.282 \\
\hline ALT, IU/L & $62.0(22.0-309.0)$ & $50.0(21.0-242.7)$ & 0.034 & $51.0(21.0-225.8)$ & $50.0(21.0-248.5)$ & 0.637 \\
\hline NT-proBNP, ng/ml & $10.9(4.6-18.6)$ & $12.1(5.1-19.8)$ & 0.019 & & & \\
\hline $\mathrm{cTnT}, \mathrm{ng} / \mathrm{mL}$ & $1.4(0.1-2.9)$ & $1.1(0.1-2.5)$ & 0.016 & $1.1(0.1-2.8)$ & $1.1(0.1-2.5)$ & 0.768 \\
\hline $\mathrm{CI}, \mathrm{L} / \mathrm{min} / \mathrm{m}^{2}$ & $2.8(2.1-3.5)$ & $2.8(2.2-3.5)$ & 0.309 & $2.8(2.1-3.4)$ & $2.8(2.2-3.5)$ & 0.938 \\
\hline Urine output, L & $1.6(0.9-2.5)$ & $1.4(0.8-2.1)$ & $<0.001$ & $1.4(0.7-2.2)$ & $1.4(0.8-2.1)$ & 0.522 \\
\hline Hospitalization type & & & 0.002 & & & 0.238 \\
\hline Emergency, n (\%) & $3498(87.6 \%)$ & $564(92.3 \%)$ & & $538(89.4 \%)$ & $555(92.2 \%)$ & \\
\hline Elective, n (\%) & $338(8.5 \%)$ & $29(4.7 \%)$ & & $39(6.5 \%)$ & $29(4.8 \%)$ & \\
\hline First ICU admission & & & $<0.001$ & & & 0.004 \\
\hline $\mathrm{CCU}, \mathrm{n}(\%)$ & $1098(27.5 \%)$ & $138(22.6 \%)$ & & $143(23.8 \%)$ & $138(22.9 \%)$ & \\
\hline Length of ICU stay, h & $93.0(50.0-184.0)$ & $109.0(54.0-204.0)$ & 0.003 & $118.5(59.0-228.8)$ & $109.0(53.0-201.8)$ & 0.128 \\
\hline \multicolumn{7}{|l|}{ Comorbidities, n (\%) } \\
\hline Hypertension & $830(20.8 \%)$ & $107(17.5 \%)$ & 0.062 & $126(20.9 \%)$ & $106(17.6 \%)$ & 0.144 \\
\hline Hyperlipemia & $1120(28.0 \%)$ & $140(22.9 \%)$ & 0.008 & $133(22.1 \%)$ & $138(22.9 \%)$ & 0.730 \\
\hline Diabetes mellitus & $1449(36.3 \%)$ & $208(34.0 \%)$ & 0.285 & $205(34.1 \%)$ & $205(34.1 \%)$ & 1.000 \\
\hline
\end{tabular}


medRxiv preprint doi: https://doi.org/10.1101/2021.08.03.21261549; this version posted August 6, 2021. The copyright holder for this preprint (which was not certified by peer review) is the author/funder, who has granted medRxiv a license to display the preprint in perpetuity.

532 Table 5. Continued.

\begin{tabular}{|c|c|c|c|c|c|c|}
\hline \multirow{2}{*}{ Parameter } & \multicolumn{3}{|c|}{ Before PSM } & \multicolumn{3}{|c|}{ After PSM } \\
\hline & $<5533.4$ & $\geqslant 5533.4$ & $P$ value & $<5533.4$ & $\geqslant 5533.4$ & $P$ value \\
\hline $\mathbf{N}$ & 3995 & 611 & & 602 & 602 & \\
\hline \multicolumn{7}{|l|}{ Comorbidities, n (\%) } \\
\hline Atrial fibrillation & $1783(44.6 \%)$ & $294(48.1 \%)$ & 0.107 & $281(46.7 \%)$ & $290(48.2 \%)$ & 0.603 \\
\hline AMI & $301(7.5 \%)$ & $45(7.4 \%)$ & 0.882 & $39(6.5 \%)$ & $44(7.3 \%)$ & 0.570 \\
\hline VHD & $402(10.1 \%)$ & $61(10.0 \%)$ & 0.952 & $88(14.6 \%)$ & $61(10.1 \%)$ & 0.018 \\
\hline Peripheral vascular & $511(12.8 \%)$ & $66(10.8 \%)$ & 0.167 & $88(14.6 \%)$ & $64(10.6 \%)$ & 0.037 \\
\hline Pulmonary circulation & $239(6.0 \%)$ & $53(8.7 \%)$ & 0.011 & $45(7.5 \%)$ & $52(8.6 \%)$ & 0.459 \\
\hline Pneumonia & $1108(27.7 \%)$ & $242(39.6 \%)$ & $<0.001$ & $235(39.0 \%)$ & $237(39.4 \%)$ & 0.906 \\
\hline COPD & $188(4.7 \%)$ & $57(9.3 \%)$ & $<0.001$ & $48(8.0 \%)$ & $53(8.8 \%)$ & 0.603 \\
\hline Liver diseases & $214(5.4 \%)$ & $18(2.9 \%)$ & 0.011 & $20(3.3 \%)$ & $18(3.0 \%)$ & 0.742 \\
\hline Renal failure & $982(24.6 \%)$ & $138(22.6 \%)$ & 0.284 & $162(26.9 \%)$ & $136(22.6 \%)$ & 0.083 \\
\hline Stroke & $227(5.7 \%)$ & $23(3.8 \%)$ & 0.051 & $38(6.3 \%)$ & $23(3.8 \%)$ & 0.052 \\
\hline Hypothyroidism & $461(11.5 \%)$ & $94(15.4 \%)$ & 0.007 & $97(16.1 \%)$ & $92(15.3 \%)$ & 0.692 \\
\hline Malignancy & $209(5.2 \%)$ & $44(7.2 \%)$ & 0.047 & $31(5.1 \%)$ & $43(7.1 \%)$ & 0.150 \\
\hline Depression & $303(7.6 \%)$ & $56(9.2 \%)$ & 0.175 & $50(8.3 \%)$ & $56(9.3 \%)$ & 0.542 \\
\hline 30-day mortality & $769(19.2 \%)$ & $204(33.4 \%)$ & $<0.001$ & $150(24.9 \%)$ & $200(33.2 \%)$ & 0.002 \\
\hline 90-day mortality & $1120(28.0 \%)$ & $260(42.6 \%)$ & $<0.001$ & $211(35.0 \%)$ & $253(42.0 \%)$ & 0.013 \\
\hline Hospital-day mortality & $659(16.5 \%)$ & $172(28.2 \%)$ & $<0.001$ & $135(22.4 \%)$ & $167(27.7 \%)$ & 0.033 \\
\hline
\end{tabular}

533

534

535

536

537

538

539

540

541

542

543

544

545

Abbreviations: PSM, propensity score matching; $\mathrm{HR}$, heart rate; RR, respiratory rate; SBP, systolic blood pressure; DBP, diastolic blood pressure; SpO2, percutaneous oxygen saturation; ACEI, angiotensin-converting enzyme inhibitors; ARB, angiotensin receptor blockers; BUN, blood urea nitrogen; PT, prothrombin time; APTT, activated partial thromboplastin time; ALT, alanine transaminase; cTnT, troponin T; NT-proBNP, N-terminal pro brain natriuretic peptide; CI, cardiac index; SII, Systemic immune-inflammation index; CHF, congestive heart failure; AMI, acute myocardial infarction; VHD, valvular heart disease; COPD, chronic obstructive pulmonary disease. CCU, cardiac care unit. 